\title{
PHAGOCYTOSIS BY HUMAN LEUCOCYTES. II. RELATION OF NUTRITIONAL DEFICIENCY IN MAN TO PHAGOCYTOSIS ${ }^{1}$
}

\author{
BY HENRY H. BALCH 2 AND MARGARET T. SPENCER
}

(From the Department of Surgery, New York University College of Medicine and the Third
(New York University) Surgical Division, Bellewne Hospital, New York, N. Y.)

(Submitted for publication February 4, 1953; accepted June 23, 1954)

It is generally believed that malnourished patients are more prone to bacterial infection than normal healthy individuals. Increased susceptibility to infection has been attributed to an impaired capacity to produce specific antibodies against the infectious agent (1) or possibly to decreased phagocytic activity resulting from nutritional deficiency (2). Quantitative data have already been presented ( 3 ) showing that emaciated patients produce antibody as well as or better than healthy control subjects so that such proneness to develop infection is probably not often related to lack of antibody production. In the present communication studies are reported on the second possibility, namely, that decreased phagocytosis in malnourished patients predisposes them to infection.

The literature relating nutritional states to phagocytosis in animals has already been reviewed by Berry and Spies (4) and need only be considered briefly here. Several groups of workers have suggested, largely on the basis of animal experiments, that nutritional deficiencies, such as specific vitamin deficiencies and protein depletion, may result in decreased phagocytic activity ; (5-9) other workers, however, have obtained conflicting results $(10-12)$. It has also been claimed that protein depletion may lead to a diminished output of leucocytes in response to the injection of bacteria or irritants $(13,14)$.

Few studies on the relationship of nutritional deficiency to the phagocytic activity of human leucocytes are to be found in the literature. Cottingham and Mills (15) reported decreased phagocytosis in 10 malnourished patients, with return

1 This study was supported in part by a contract with the Medical Research and Development Board of the Office of the Surgeon General, U. S. Army.

2 Markle Scholar in Medical Science. Present Address : Division of Surgery, Army Medical Service Graduate School, Walter Reed Army Medical Center, Washington 12, D. C. to normal as the nutritional states improved; six of these were suffering from acute bacillary dysentery. These investigators suggested that improved phagocytosis might be due to the release of new phagocytes from bone marrow, which had been produced when the nutritional state improved. Berry, Davis, and Spies (16) reported that the phagocytic activity of the neutrophils from patients with mixed dietary deficiency was often 50 per cent or more below control values. On the other hand, Feller, Roberts, Ralli, and Francis (17) noted no significant change in phagocytosis in patients on vitamin $\mathrm{A}$ or vitamin $\mathrm{C}$ deficient diets. Bieler, Ecker, and Spies (18) noted normal opsonic indices in blood from eight hypoproteinemic, nutritionally deficient patients ; and Berry, Leyendecker, and Spies (19) reported increased ingestion in studies on the phagocytic activity of leucocytes in anemic blood. In the latter study many of the subjects were malnourished.

The present paper is a report of in vitro studies on the phagocytic activity of neutrophilic polymorphonuclear leucocytes taken from well nourished and severely malnourished patients. This study was carried out in conjunction with the observations reported in the preceding paper. Data with reference to phagocytosis in normal subjects are taken from that paper (20).

\section{METHOD}

Phagocytosis was measured in 20 severely malnourished patients and 17 healthy control subjects. The method, utilizing the roller tube technique, has been described in detail in the previous paper. Phagocytosis was measured in both coagulable and non-coagulable blood using a coagulase negative ( $\mathrm{C}-$ ) strain of staphylococcus and four coagulase positive strains ( $C+I$, II, III, IV) used in the previous study (20).

The nutritional state of the patients was determined from the clinical history, by measuring weight loss or gain and by serum protein estimations. Serum albumin and globulin were measured by the Kingsley (21) modification of Howe's method, using 23 per cent sodium sul- 
TABLE I

Ingestion of staphylococci by neutrophils in blood containing heparin or streptokinase or in blood defibrinated with glass beads (Roller tube technique-Malnourished patients)

\begin{tabular}{|c|c|c|c|c|c|c|}
\hline Blood preparation & $\begin{array}{l}\text { Number of } \\
\text { subjects }\end{array}$ & $\begin{array}{l}\text { Average } \\
\text { neutrophil } \\
\text { count per } \\
\text { cu. } \mathbf{m m} \text {. }\end{array}$ & $\begin{array}{c}\text { Number } \\
\text { neutrophils } \\
\text { counted }\end{array}$ & $\begin{array}{l}\text { Micro- } \\
\text { organism* }\end{array}$ & $\begin{array}{c}\text { Mean } \\
\text { ingestion } \\
\text { per } \\
\text { neutrophil }\end{array}$ & $\begin{array}{c}\text { Standard } \\
\text { error }\end{array}$ \\
\hline Blood plus heparin & $\begin{array}{l}20 \\
20\end{array}$ & 5,680 & $\begin{array}{l}4,000 \\
1,000\end{array}$ & $\stackrel{\mathbf{C}}{\mathbf{C}-}$ & $\begin{array}{l}14.6 \\
19.3\end{array}$ & $\begin{array}{l} \pm 1.0 \\
\pm 2.0\end{array}$ \\
\hline $\begin{array}{l}\text { Blood plus } \\
\text { streptokinase }\end{array}$ & $\begin{array}{l}18 \\
17\end{array}$ & 6,700 & $\begin{array}{r}3,600 \\
850\end{array}$ & $\stackrel{\mathrm{C}}{\mathrm{C}}-$ & $\begin{array}{l}20.7 \\
21.7\end{array}$ & $\begin{array}{l} \pm 2.2 \\
\pm 2.7\end{array}$ \\
\hline $\begin{array}{l}\text { Defibrinated } \dagger \\
\text { blood }\end{array}$ & $\begin{array}{l}20 \\
19\end{array}$ & 5,800 & $\begin{array}{r}4,000 \\
950\end{array}$ & $\stackrel{\mathrm{C}+}{\mathrm{C}-}$ & $\begin{array}{l}30.7 \\
25.7\end{array}$ & $\begin{array}{l} \pm 3.4 \\
\pm 3.5\end{array}$ \\
\hline $\begin{array}{l}\text { Defibrinated blood } \\
\text { plus streptokinase } \dagger\end{array}$ & $\begin{array}{l}20 \\
20\end{array}$ & 5,800 & $\begin{array}{l}4,000 \\
1,000\end{array}$ & $\stackrel{\mathrm{C}}{\mathrm{C}}-$ & $\begin{array}{l}28.0 \\
18.2\end{array}$ & $\begin{array}{l} \pm 2.7 \\
\pm 1.8\end{array}$ \\
\hline
\end{tabular}

* CH+ = Coagulase positive strains I, II, III, IV.

$\mathrm{C}-=$ Coagulase negative.

+ Defibrinated with glass beads.

fate for separation of albumin and globulin. Plasma volume was estimated by the Evans blue dye method, using a Coleman junior spectrophotometer to measure dye concentration. In each case the clinical course was followed carefully and correlated with the above data. The control cases were selected from patients and hospital personnel considered to be well nourished and in good health. Malnourished patients were selected from cases with advanced wasting disease.

No patients received antibacterial drugs while under study.

\section{RESULTS}

Ingestion of $(C+)$ and of $(C-)$ staphylococci by neutraphils from malnourished patients

Table I records mean ingestion of $(\mathrm{C}+)$ and (C-) staphylococci by neutrophils from malnourished patients. As in the experiments re- ported in the previous paper, four different blood preparations were used (whole blood plus heparin, whole blood plus streptokinase, blood defibrinated with glass beads, and the latter to which streptokinase had been added). Mean ingestion of all coagulase positive strains (I, II, III, and IV) has been recorded, because phagocytosis was not significantly different with individual strains.

The findings reported in this table are almost identical with those found in the study of normal subjects (20) and may be briefly summarized. There was no significant difference in mean ingestion of $(\mathrm{C}-)$ staphylococci in the different blood preparations, so that under the experimental conditions used, heparin, streptokinase, or defibrination of blood with glass beads did not in-

TABLE II

Ingestion of staphylococci by neutrophils in blood from normal and malnourished subjects

\begin{tabular}{|c|c|c|c|c|c|}
\hline \multirow[b]{2}{*}{ Blood preparation } & \multirow[b]{2}{*}{$\begin{array}{c}\text { Micro- } \\
\text { organism }\end{array}$} & \multicolumn{2}{|c|}{ Normal* } & \multicolumn{2}{|c|}{ Malnourished* } \\
\hline & & $\begin{array}{c}\text { Mean } \\
\text { ingestion } \\
\text { per } \\
\text { neutrophil }\end{array}$ & $\begin{array}{c}\text { Standard } \\
\text { error }\end{array}$ & $\begin{array}{c}\text { Mean } \\
\text { ingestion } \\
\text { per } \\
\text { neutrophil }\end{array}$ & $\begin{array}{c}\text { Standard } \\
\text { error }\end{array}$ \\
\hline Blood plus heparin & $\stackrel{\mathrm{C}+}{\mathrm{C}-}$ & $\begin{array}{l}15.7 \\
20.4\end{array}$ & $\begin{array}{l} \pm 1.0 \\
\pm 1.8\end{array}$ & $\begin{array}{l}14.6 \\
19.3\end{array}$ & $\begin{array}{l} \pm 1.0 \\
\pm 2.0\end{array}$ \\
\hline $\begin{array}{l}\text { Blood plus } \\
\text { streptokinase }\end{array}$ & $\stackrel{\mathrm{C}}{\mathrm{C}}-$ & $\begin{array}{l}23.0 \\
23.7\end{array}$ & $\begin{array}{l} \pm 2.8 \\
\pm 2.6\end{array}$ & $\begin{array}{l}20.7 \\
21.7\end{array}$ & $\begin{array}{l} \pm 2.2 \\
\pm 2.7\end{array}$ \\
\hline $\begin{array}{l}\text { Defibrinated } \\
\text { blood }\end{array}$ & $\stackrel{\text { C+ }}{\mathbf{C}-}$ & $\begin{array}{l}32.7 \\
22.0\end{array}$ & $\begin{array}{l} \pm 1.6 \\
\pm 1.7\end{array}$ & $\begin{array}{l}30.7 \\
25.7\end{array}$ & $\begin{array}{l} \pm 3.4 \\
\pm 3.5\end{array}$ \\
\hline $\begin{array}{l}\text { Defibrinated blood } \\
\text { plusstreptokinase }\end{array}$ & $\stackrel{\mathrm{C}+}{\mathrm{C}-}$ & $\begin{array}{l}33.5 \\
23.9\end{array}$ & $\begin{array}{l} \pm 1.6 \\
\pm 1.9\end{array}$ & $\begin{array}{l}28.0 \\
18.2\end{array}$ & $\begin{array}{l} \pm 2.7 \\
\pm 1.8\end{array}$ \\
\hline
\end{tabular}

* 17 normal and 20 malnourished subjects. 
TABLE III

Phagocytic index related to age and serum proteins-Well nourished subjects

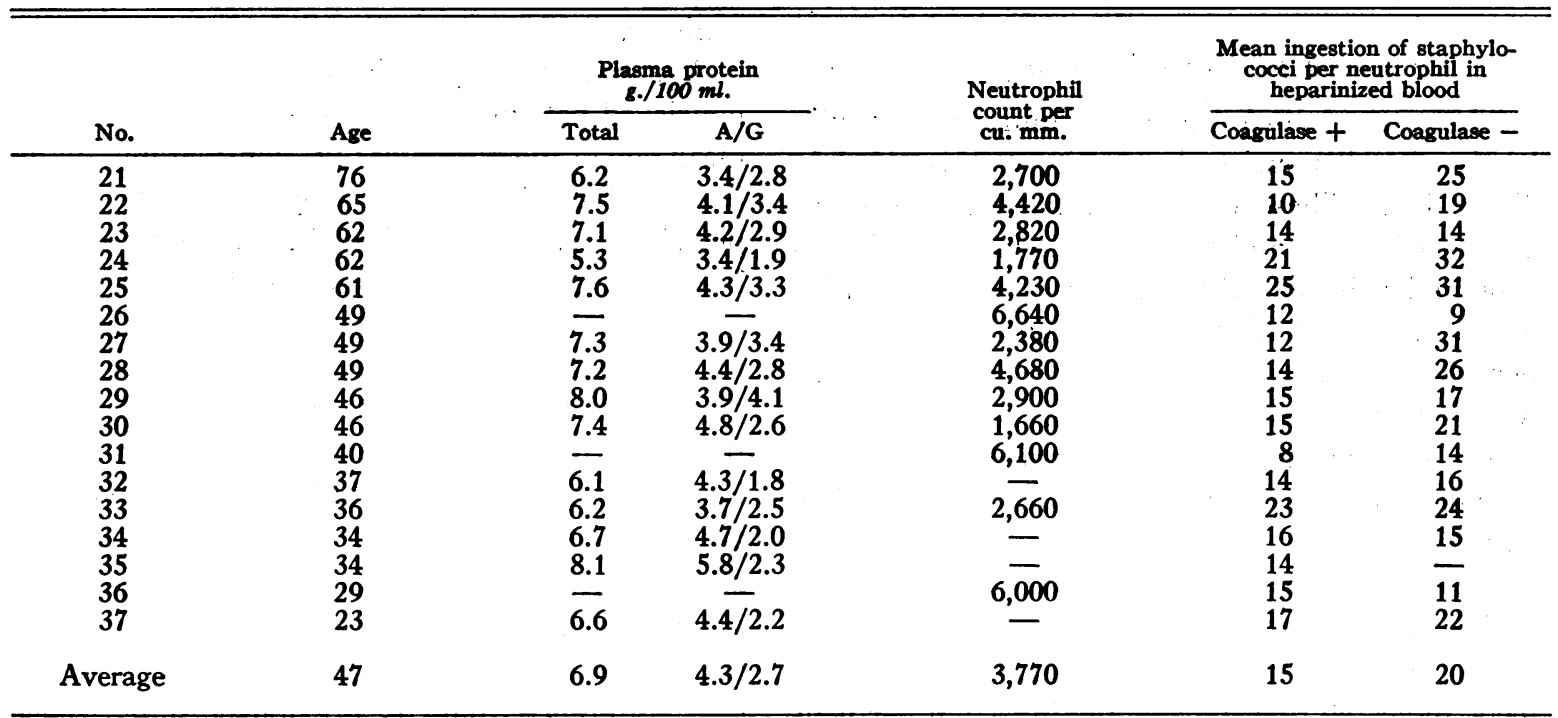

fluence phagocytosis. On the other hand, there was a significant reduction in phagocytosis of (C+) staphylococci associated with the production of fibrin in heparinized blood; mean ingestion of this microorganism was greater in streptokinase-treated blood but still significantly reduced compared with ingestion in blood defibrinated with glass beads.

Comparison of ingestion of $(\mathrm{C}+)$ with $(\mathrm{C}-)$ staphylococci in heparinized blood and defibrinated blood showed significant differences. Fewer (C+) microorganisms were ingested in heparinized blood while the reverse obtained in defibrinated blood.

Thus, when tested in heparinized blood there was diminished mean ingestion of coagulase-producing staphylococci by neutrophils from malnourished patients. The addition of streptokinase to blood to remove fibrin allowed increased but not maximal ingestion of $(\mathrm{C}+)$ staphylococci.

\section{Comparison of phagocytosis in normal and mal- nourished subjects}

Table II lists mean ingestion of staphylococci by neutrophils from normal and malnourished subjects. Comparison of the data showed no significant difference between the groups. The average neutrophil count per cubic millimeter in the malnourished patients ranged from 50 to 90 per cent higher than in the series of normal individuals. Jung and Hanks $(22,23)$ found that as the ratio of leucocytes to microorganisms increased, mean ingestion decreased. This was not found under the experimental conditions used in this study where the ratio of bacteria to neutrophils was approximately $27: 1$. Data relating neutrophil count per cubic millimeter to mean ingestion of the $(\mathrm{C}+)$ strain I and the $(\mathrm{C}-)$ staphylococcal strain in individual malnourished patients are given in Table V. No consistent relation can be seen, confirming the observations noted in the previous

\section{TABLE IV}

Phagocytic index in two well nourished subjects repeated at weekly intervals

\begin{tabular}{|c|c|c|}
\hline \multicolumn{3}{|c|}{$\begin{array}{c}\text { No. } 32 \text { Mean ingestion of staphylo- } \\
\text { cocci per neutrophil in } \\
\text { heparinized blood }\end{array}$} \\
\hline & Coagulase + & Coagulase - \\
\hline $\begin{array}{l}\text { 1st week } \\
\text { 2nd week } \\
\text { 3rd week } \\
\text { 4th week }\end{array}$ & $\begin{array}{l}14 \\
16 \\
19 \\
20\end{array}$ & $\begin{array}{l}16 \\
26 \\
34 \\
18\end{array}$ \\
\hline \multicolumn{3}{|c|}{ No. 34} \\
\hline $\begin{array}{l}\text { 1st week } \\
\text { 2nd week } \\
\text { 3rd week } \\
\text { 4th week }\end{array}$ & $\begin{array}{l}16 \\
24 \\
19 \\
32\end{array}$ & $\begin{array}{l}15 \\
39 \\
27 \\
30\end{array}$ \\
\hline
\end{tabular}


paper (20) and also the findings of another group of investigators (17).

\section{Age and serum protein related to phagocytosis}

The age, serum protein, albumin, and globulin levels of well nourished subjects are recorded in Table III. These data are related to mean ingestion of $(\mathrm{C}+)$ and $(\mathrm{C}-)$ staphylococci. Serum protein levels fell within accepted normal limits, except in patient No. 24 ; the mean was 6.9 grams per $100 \mathrm{ml}$. Five of the albumin determinations were below 4.0 grams per $100 \mathrm{ml}$. ; the others were above this arbitrary normal range. Albumin/ globulin ratios were normal with one exception, patient No. 29.

Mean ingestion of staphylococci per neutrophil varied considerably. Phagocytosis studied at weekly intervals in two of the well nourished subjects, indicated that the average ingestion per neutrophil was not constant even in a particular individual (Table IV). This is in agreement with the findings of others (17) and points out one of the difficulties in obtaining significant data in a study of this nature.

None of the data recorded in Table III showed any consistent relation to mean ingestion of staphylococci; so, under the conditions studied, age, total serum protein, albumin, and globulin did not seem to be related to phagocytosis in normal subjects.

Age and serum protein determinations of malnourished patients are recorded in Table $V$. The mean age of the group was 68 , considerably higher than that of the normal subjects. Total serum proteins varied widely, but the albumin level was below 4.0 grams per $100 \mathrm{ml}$. in all but two cases and in 12 of these was below 3.0 grams per 100 $\mathrm{ml}$. Albumin/globulin ratios were reversed in 14 of the patients. As in the well nourished group, there was no consistent relation between the mean ingestion of staphylococci in heparinized blood and the patient's age, the level of total serum protein, albumin, or globulin. Comparison of albumin and globulin means (standard error in each $= \pm 0.2$ ) in the two groups of subjects revealed a significant difference; but, as previously stated, mean ingestion of staphylococci between the groups was about equal.

The significance of serum protein levels may be difficult to assess from single determinations because of acute or chronic changes in plasma volume; therefore, blood volumes were determined in five unselected patients from each series. Total circulating serum protein, albumin, and globulin

TABLE V

Phagocytic index related to age and serum proteins-Malnourished subjects

\begin{tabular}{|c|c|c|c|c|c|c|}
\hline \multirow[b]{2}{*}{ No. } & \multirow[b]{2}{*}{ Age } & \multicolumn{2}{|c|}{$\begin{array}{l}\text { Plasma protein } \\
\quad 8 . / 100 \mathrm{ml} .\end{array}$} & \multirow{2}{*}{$\begin{array}{l}\text { Neutrophil } \\
\text { count per } \\
\text { cu. mm. }\end{array}$} & \multicolumn{2}{|c|}{$\begin{array}{l}\text { Mean ingestion of staphylo- } \\
\text { cocel per neutrophil in } \\
\text { heparinized blood }\end{array}$} \\
\hline & & Total & A/G & & Coagulase + & Coagulase - \\
\hline $\begin{array}{r}1 \\
2 \\
3 \\
4 \\
5 \\
6 \\
7 \\
8 \\
9 \\
10 \\
11 \\
12 \\
13 \\
14 \\
15 \\
16 \\
17 \\
18 \\
19 \\
20\end{array}$ & $\begin{array}{l}86 \\
83 \\
78 \\
77 \\
76 \\
74 \\
74 \\
72 \\
71 \\
71 \\
70 \\
67 \\
65 \\
64 \\
63 \\
63 \\
63 \\
56 \\
54 \\
32\end{array}$ & $\begin{array}{l}6.0 \\
7.5 \\
5.7 \\
7.1 \\
6.5 \\
5.6 \\
5.6 \\
5.3 \\
7.5 \\
6.4 \\
7.3 \\
6.2 \\
4.4 \\
7.5 \\
8.3 \\
5.5 \\
6.1 \\
5.6 \\
6.7\end{array}$ & $\begin{array}{l}2.6 / 3.4 \\
4.1 / 3.4 \\
2.7 / 3.0 \\
3.7 / 3.4 \\
3.4 / 3.1 \\
2.5 / 3.1 \\
2.7 / 2.9 \\
2.1 / 3.2 \\
2.9 / 4.6 \\
1.7 / 4.7 \\
3.1 / 4.2 \\
2.7 / 3.5 \\
2.0 / 2.4 \\
2.5 / 5.0 \\
3.7 / 4.6 \\
3.3 / 2.2 \\
2.0 / 4.1 \\
2.2 / 3.4 \\
4.0 / 2.7\end{array}$ & $\begin{array}{r}10,100 \\
9,620 \\
1,810 \\
8,400 \\
2,110 \\
4,250 \\
2,890 \\
1,580 \\
8,130 \\
6,320 \\
2,160 \\
6,340 \\
4,070 \\
5,900 \\
3,460 \\
2,280 \\
21,000 \\
5,100 \\
2,680\end{array}$ & $\begin{array}{r}10 \\
15 \\
19 \\
10 \\
16 \\
18 \\
20 \\
7 \\
14 \\
15 \\
13 \\
9 \\
10 \\
12 \\
16 \\
21 \\
19 \\
6 \\
16 \\
21\end{array}$ & $\begin{array}{r}12 \\
12 \\
35 \\
18 \\
17 \\
13 \\
37 \\
6 \\
23 \\
20 \\
28 \\
10 \\
17 \\
11 \\
20 \\
27 \\
29 \\
11 \\
33 \\
27\end{array}$ \\
\hline Average & 68 & 6.4 & $2.8 / 3.5$ & 5,680 & 14 & 20 \\
\hline
\end{tabular}


TABLE VI

Phagocytic index related to total circulating plasma protein, plasma albumin, plasma globulin and total red cell mass

\begin{tabular}{|c|c|c|c|c|c|c|c|c|c|}
\hline \multirow[b]{3}{*}{$\begin{array}{l}\text { Patient } \\
\text { number }\end{array}$} & \multirow[b]{3}{*}{ Age } & \multirow{3}{*}{$\begin{array}{c}\text { Plasma } \\
\text { protein } \\
\text { g. } / 100 \mathrm{ml} .\end{array}$} & \multicolumn{3}{|c|}{ Total circulating } & \multirow{3}{*}{$\begin{array}{c}\text { Total } \\
\text { red cell } \\
\text { mass } \\
\text { ml. }\end{array}$} & \multirow{3}{*}{$\begin{array}{c}\text { Approximate } \\
\text { number } \\
\text { circulating } \\
\text { neutrophils } \\
\times 10^{\circ}\end{array}$} & \multirow{2}{*}{\multicolumn{2}{|c|}{$\begin{array}{l}\text { Mean ingestion } \\
\text { of staphylococe } \\
\text { per neutrophil in } \\
\text { heparinized blood }\end{array}$}} \\
\hline & & & \multirow{2}{*}{$\begin{array}{l}\begin{array}{l}\text { Plasma } \\
\text { protein } \\
\text { 8. }\end{array} \\
\end{array}$} & \multirow{2}{*}{$\begin{array}{c}\text { Plasma } \\
\text { albumin } \\
8 .\end{array}$} & \multirow{2}{*}{$\begin{array}{c}\text { Plasma } \\
\text { globulin } \\
\text { 8. }\end{array}$} & & & & \\
\hline & & & & & & & & $\mathrm{c}+$ & C- \\
\hline \multicolumn{10}{|c|}{ Well nourished group } \\
\hline $\begin{array}{l}23 \\
24 \\
27 \\
28 \\
29\end{array}$ & $\begin{array}{l}62 \\
62 \\
49 \\
48 \\
46\end{array}$ & $\begin{array}{l}7.1 \\
5.3 \\
7.4 \\
7.2 \\
8.0\end{array}$ & $\begin{array}{l}242 \\
201 \\
204 \\
268 \\
395\end{array}$ & $\begin{array}{l}143 \\
129 \\
109 \\
163 \\
195\end{array}$ & $\begin{array}{r}99 \\
72 \\
95 \\
105 \\
200\end{array}$ & $\begin{array}{l}2,750 \\
4,090 \\
2,895 \\
2,660 \\
3,620\end{array}$ & $\begin{array}{l}21 \\
15 \\
18 \\
38 \\
29\end{array}$ & $\begin{array}{l}14 \\
21 \\
12 \\
14 \\
15\end{array}$ & $\begin{array}{l}14 \\
32 \\
31 \\
26 \\
17\end{array}$ \\
\hline Mean & 53 & 7.0 & 262 & 147 & 114 & 3,200 & 24 & 15 & 24 \\
\hline \multicolumn{10}{|c|}{ Malnourished group } \\
\hline $\begin{array}{r}3 \\
6 \\
9 \\
13 \\
16\end{array}$ & $\begin{array}{l}78 \\
74 \\
71 \\
65 \\
63\end{array}$ & $\begin{array}{l}5.7 \\
5.6 \\
7.5 \\
4.4 \\
5.5\end{array}$ & $\begin{array}{l}180 \\
163 \\
190 \\
113 \\
145\end{array}$ & $\begin{array}{l}87 \\
73 \\
75 \\
50 \\
88\end{array}$ & $\begin{array}{r}93 \\
90 \\
115 \\
63 \\
57\end{array}$ & $\begin{array}{l}1,150 \\
2,480 \\
1,800 \\
1,330 \\
1,730\end{array}$ & $\begin{array}{r}9 \\
28 \\
40 \\
27 \\
19\end{array}$ & $\begin{array}{l}19 \\
18 \\
14 \\
10 \\
21\end{array}$ & $\begin{array}{l}35 \\
13 \\
23 \\
17 \\
27\end{array}$ \\
\hline Mean & 70 & 5.7 & 158 & 75 & 84 & 1,700 & 25 & 16 & 23 \\
\hline
\end{tabular}

were calculated and are recorded in Table VI. The mean value for total protein and albumin was 60 and 51 per cent lower in the malnourished patients; but mean ingestion of staphylococci in the two groups was not significantly different.

\section{Anemia and phagocytosis}

Berry and his associates $(19,24-26)$ have reported that leucocytes from anemic blood show more active phagocytosis than those obtained from patients with normal red cell counts. It is believed by these authors that the neutrophils from anemic blood have undergone some fundamental change which did not appear related to increased motility but which endowed them with greater phagocytic capacity than normal cells. Table VI records the total circulating red cell mass of five patients from each of the nutritional groups. The difference between the two groups is marked, but this is not reflected in any significant difference in phagocytosis. Therefore, under the conditions of the present experiments, there was no significant difference in the phagocytic activity of leucocytes taken from anemic and normal patients.

Total circulating neutrophils in normal and malnourished subjects

Table VI also records a rough approximation of the number of circulating neutrophils present in the five normal and five malnourished subjects. These were calculated by determining neutrophil count per cubic millimeter and multiplying this figure by the known blood volume. The error inherent in these estimations was probably of the same order in the two groups of patients. There was no significant difference in numbers of neutrophils between the groups.

\section{Clinical state of subjects studied}

A brief description of the clinical picture presented by the malnourished patients is recorded in Table VII, which indicates the severe degree of disease present. Findings commonly associated with far advanced wasting disease, such as extensive weight loss, emaciation, decubitus ulcers, asthenia, and anemia, were present in many of the patients. Blood was taken for study from several patients within three days of death.

\section{DISCUSSION}

The data presented in this paper show that there was no significant difference in the mean phagocytosis of staphylococci by neutrophils from the normal and malnourished patients studied. The mean age of the two groups was different, but there was no evidence that patient age is a factor in phagocytosis. The microorganisms used in the study were selected for two reasons: 1) Staphylococci may be associated with infections in mal- 
TABLE VII

Diagnosis and clinical course in malnourished patients*

Patient

No.

1. Carcinoma of head of pancreas with obstructive jaundice; 2-year history; patient emaciated and terminal in appearance; died. (10)

2. General and cerebral arteriosclerosis; prostatic hypertrophy; patient confined to room for 3 years with inadequate care; emaciated; discharged to State Mental Institution.

3. Femoral neck fracture; chronic alcoholism with portal cirrhosis; transferred unimproved.

4. Emaciated patient admitted to hospital in terminal state; unable to eat; undiagnosed; died. (1)

5. Carcinoma of sigmoid colon; admitted with intestinal obstruction requiring cecostomy followed by transverse colostomy. Progressive weight loss; transferred to State Mental Institution, unimproved.

6. Metastatic carcinoma of liver with 80-pound weight loss during preceding 12 months; repeated massive rectal hemorrhages; died. (3)

7. Adenocarcinoma of rectum with metastases. Progressive weight loss and emaciated in appearance. Apparently terminal; died. (2)

8. Chronic alcoholism with malnutrition and 20-pound weight loss; leg ulcers; improved with adequate diet.

9. Carcinoma of esophagus; history of progressive dysphagia for 1 year; 50-pound weight loss; decubitus ulcers and peripheral edema; died. (8)

10. Laennec's cirrhosis with ascites and peripheral edema ; weight loss; discharged unimproved.

11. Emaçiated patient with large decubitus ulcers admitted in uremia; died without a diagnosis. (2)

12. Adenocarcinoma of rectum with metastases to bladder, peritoneum and liver; ascites; discharged unimproved.

13. Probable carcinoma of stomach with pyloric obstruction. Pulmonary tuberculosis; died. (3)

14. Amyotrophic lateral sclerosis with 30 -pound weight loss and large decubitus ulcers. Unimproved. (42)

15. Unknown.

16. Colonic diverticulosis. History of chronic diarrhea of 3-4 years' duration; 30- to 40-pound weight loss. Discharged improved.

17. Laennec's cirrhosis with ascites and peripheral edema. Transferred unimproved.

18. Carcinoma of lung; extremely wasted with extensive decubitus ulcer; course rapidly deteriorating. Transferred unimproved.

19. Carcinoma of lung with metastases; 40 to 45 -pound weight loss; progressive deterioration. Discharged unimproved.

20. Benign stricture of esophagus requiring gastrostomy. Best weight 105 pounds, present weight 71 pounds. Discharged improved.

* Figures in parentheses indicate interval (in days) between determination of phagocytic index and death.

nourished patients ; 2 ) It seemed possible that a defect in phagocytosis might appear only if a microorganism was used which was somewhat resistant to ingestion. This was investigated by comparing the ingestion of both $(\mathrm{C}+)$ and $(\mathrm{C}-)$ staphylococci in heparinized blood; diminished ingestion might then have become apparent only with the $(\mathrm{C}+)$ strain.
The data show that under the experimental conditions neutrophil count did not significantly influence mean ingestion; therefore, the fact that the mean neutrophil count was higher in the malnourished group does not alter the significance of the comparison of phagocytic indices found.

There can be little doubt that the patients included in the malnourished group were severely wasted. Hypoproteinemia was a prominent feature in many of the cases although in some of these starvation was not the only factor. Carcinoma with metastases was the primary cause of death in nine of the patients. Cachexia, associated with carcinoma, may be due to several causes, so it is possible that the high phagocytic indices found in such cases may not truly represent the state of neutrophil activity likely to be present in uncomplicated malnutrition. Nevertheless, phagocytic indices were normal in two of the three patients studied (numbers 2 and 20) in whom malnutrition was due to simple starvation; and they were also normal in the three patients with portal cirrhosis of the liver, a lesion thought to be associated with inadequate diet. Blood for study was drawn within three days of death from wasting disease in five of the patients; yet mean ingestion by the neutrophils was normal. It seems probable, therefore, that phagocytosis of staphylococci by neutrophils may be normal regardless of the nutritional state of a patient, provided maturation has occurred and a suitable environment is present.

The possibility remains that malnourished patients may not have the capacity to produce sufficient numbers of normal neutrophils in response to a prolonged stimulus. The data presented in Table VI showing the approximate number of circulating neutrophils in normal and malnourished patients are of interest, although probably insufficient from which to draw general conclusions. In four of the malnourished patients (numbers 6 , 9,13 , and 16), the total circulating neutrophil count was comparable to control values; moreover, the mean ingestion by these neutrophils was also comparable. The first three of these patients were among the most severely wasted of the entire group, disease having been present for several months. In two of the patients, blood was drawn for study three days before death and in the third, eight days before death. These cases show quite 
definitely that a patient may possess normal numbers of viable neutrophils in the circulation following prolonged starvation.

The findings of this study are not comparable with some of the other reported studies on malnutrition and phagocytosis (5-9). Much of the previous work has been done with leucocytes from animals which have been on protein or specific vitamin deficient diets; furthermore, staphylococcus was not always used to test ingestion. The results of the present study cannot be compared with those reported in a series of patients with acute dysentery (15), because no patient with that diagnosis was included. Furthermore, the techniques used were not identical, and phagocytic activity in the dysentery patients was reported only as the per cent of that of two normal controls. It is possible that the severe changes in intravascular water and electrolyte content which are frequently present in acute dystentery may have altered the environment necessary for optimal phagocytosis. The improvement in phagocytosis recorded as the symptoms of dysentery abated may have been a reflection of restoration of the normal plasma volume. The findings of this paper agree with one study (19) and disagree with another (16) found in the literature on phagocytosis in malnourished patients.

The present studies failed to show increased phagocytosis in relation to anemia. Berry and Spies (4) were only able to show such a relationship by adjusting the in vitro phagocytic system so that the number of leucocytes in anemic and normal blood was comparable. Our findings may be different, therefore, because no attempt was made to control this variable, although the experiments did not show leucocyte count to be an important factor. Another possible explanation for the failure to confirm the findings of the above investigators is that a larger ratio of microorganisms to leucocytes was used in the present study. Because mean ingestion in our controls was relatively large, the technique may not have permitted the demonstration of any further increase.

In a previous paper quantitative evidence was presented to show that patients may still produce large amounts of antibody within a few days of terminal wasting disease (3). The present report shows that similar patients may also produce normal quantities of neutrophils shortly before death which can ingest staphylococci with ease. Therefore, the increased incidence of infection found in malnourished patients is probably not often related to a defect in the above defense mechanisms.

\section{SUMMARY}

1. Phagocytosis of four coagulase positive and one coagulase negative staphylococcal strains has been studied in 17 well nourished subjects and in 20 patients with advanced wasting disease.

2. There was no significant difference in the ingestion of staphylococci by the neutrophil polymorphonuclear leucocytes obtained from these two groups. Phagocytosis could not be related to serum protein levels, total red cell mass, or age of the patient.

\section{REFERENCES}

1. Cannon, P. R., Wissler, R. W., Woolridge, R. L., and Benditt, E. P., The relationship of protein deficiency to surgical infection. Ann. Surg., 1944, $120,514$.

2. Cannon, P. R., The importance of proteins in resistance to infection. J. A. M. A., 1945, 128, 360.

3. Balch, H. H., Relation of nutritional deficiency in man to antibody production. J. Immunol., 1950, 64, 397.

4. Berry, L. J., and Spies, T. D., Phagocytosis. Medicine, 1949, 28, 239.

5. Gellhorn, E., and Dunn, J. O., Undernutrition, starvation and phagocytosis. J. Nutrition, 1937, 14, 145.

6. Riddle, J. W., Spies, T. D., and Hudson, N. P., A note on the interrelationship of deficiency diseases and resistance to infection. Proc. Soc. Exper. Biol. \& Med., 1940, 45, 361.

7. Cottingham, E., and Mills, C. A., Influence of environmental temperature and vitamin-deficiency upon phagocytic functions. J. Immunol., 1943, 47, 493.

8. Mills, C. A., and Cottingham, E., Phagocytic activity as affected by protein-intake in heat and cold. J. Immunol., 1943, 47, 503.

9. Berry, L. J., Davis, J., and Spies, T. D., The relationship between diet and the mechanisms for defense against bacterial infections in rats. J. Lab. \& Clin. Med., 1945, 30, 684.

10. Findlay, G. M., and Mackenzie, R., Opsonins and diets deficient in vitamins. Biochem. J., 1922, 16, 574.

11. Werkman, C. H., Immunologic significance of vitamins. III. Influence of the lack of vitamins on the leucocytes and on phagocytosis. J. Infect. Dis., 1923, 32, 263.

12. Guggenheim, K., and Buechler, E., Nutrition and resistance to infection. Bactericidal properties and 
phagocytic activity of peritoneal fluid of rats in various states of nutritional deficiency. J. Immunol., 1946, 54, 349.

13. Wissler, R. W., The effects of protein-depletion and subsequent immunization upon the response of animals to pneumococcal infection. I. Experiments with rabbits. J. Infect. Dis., 1947, 80, 250.

14. Asirvadham, M., The bone marrow and its leucocytic response in protein deficiency. J. Infect. Dis., 1948, 83, 87.

15. Cottingham, E., and Mills, C. A., Timing of phagocytic changes in malnutrition. J. Lab. \& Clin. Med., 1945, 30, 498.

16. Berry, L. J., Davis, J., and Spies, T. D., (Phagocytosis) unpublished observations reported by Berry, L. J., and Spies, T. D., Phagocytosis. Medicine, 1949, 28, 239.

17. Feller, A. E., Roberts, L. B., Ralli, E. P., and Francis, T., Jr., Studies on the influence of vitamin A and vitamin $C$ on certain immunological reactions in man. J. Clin. Invest., 1942, 21, 121.

18. Bieler, M. M., Ecker, E. E., and Spies, T. D., Serum proteins in hypoproteinemia due to nutritional deficiency. J. Lab. \& Clin. Med., 1947, 32, 130.

19. Berry, L. J., Leyendecker, R. M., and Spies, T. D., Comparative studies of phagocytosis in normal and in anemic blood. Blood, 1947, Special Issue No. $1,98$.

20. Balch, H. H., and Spencer, M. T., Phagocytosis by human leucocytes. I. Effect of fibrin on phagocytosis of staphylococci and of encapsulated pneumococci by normal human leucocytes. J. Clin. Invest., 1954, 33, 1314.

21. Kingsley, G. R., The direct biuret method for the determination of serum proteins as applied to photoelectric and visual colorimetry. J. Lab. \& Clin. Med., 1942, 27, 840.

22. Jung, R. W., The importance of leucocyte counts in phagocytic tests. J. Lab. \& Clin. Med., 1936, 21,760 .

23. Hanks, J. H., Quantitative aspects of phagocytosis as influenced by the number of bacteria and leucocytes. J. Immunol., 1940, 38, 159.

24. Berry, L. J., Davis, J., and Spies, T. D., Phagocytic activity of neutrophils in anemias. J. Lab. \& Clin. Med., 1945, 30, 910.

25. Berry, L. J., and Haller, E. C., The influence of anemia on phagocytic functions in rats. Blood, 1947, Special Issue No. 1, 108.

26. Berry, L. J., and Haller, E. C., The influence of anemia on phagocytic functions and resistance to infections in mice. Blood, 1947, Special Issue No. 1, 117. 